\title{
The role of access to information in trading relationship and plans for future activities
}

\author{
Sadik Maloku \\ Faculty of Life and Environmental Sciences, \\ University "Ukshin Hoti” Prizren, \\ Kosovo \\ sadik.maloku@,uni-prizren.com
}

\section{Gentjan Çera}

Faculty of Management and Economics, Tomas Bata University in Zlin,

Crech Republic

cera@utb.cz.

ORCID 0000-0002-9324-181X

\section{Zdenko Metzker}

Faculty of Management and Economics,

Tomas Bata University in Zlin,

Crech Republic

metrken@utb.cz.

\section{Isuf Lushi}

Faculty of Life and Environmental Sciences, University "Ukshin Hoti" Prizren,

Kosovo, Corresponding author

isuf.lushi@uni-prizren.com

\section{Bekim Poleshi}

Faculty of Economics and Administrative Sciences, Epoka University, Albania

bpoleshi19@epoka.edu.al

Abstract. The goal of this study is to investigate the role of market information on the quality of the relationship between farmers and their buyers, and also plans for future activities in a farm. Although there is research which sheds light on the role of communication and shared information between the trading partners, yet there is a need to provide sound evidence that brings more clarity to the role of market information in different aspects of trading relationships. Primary data are collected and analysed with the aim to test the above linkages.

Received: April, 2020 1st Revision: March, 2021 Accepted: May, 2021

DOI: 403 complete questionnaires have been collected in different agribusiness areas 8330.2021/14-2/8 
structured equation modelling (PSL-SEM) was used. Reliability, discriminant and path analyses were done. The results show that market information positively affects the relationship quality (satisfaction, commitment and trust), while plans for future activities are influenced by farmer's commitment, trust, and age, and also incomes from agricultural activities. This work contributes to the existing literature, in particular in the agribusiness field, by offering extra evidence from a developing country context.

Keywords: relationship quality, satisfaction, commitment, trust, market information, future activities.

JEL Classification: Q12, Q13

\section{INTRODUCTION}

From the economic and financial points of view, the world is undergoing rapid changes. The market environment is getting more and more globalized, while its competitiveness and complexity are increasing (Muo \& Azeez, 2019). Of course, these trends can be also observed in Albania, a developing country with an economy mainly driven by agriculture. The reality is very dynamic, so are the relationships between economic agents. When doing business between buyers and sellers, uncertainties and risks are always present. This highlights the great importance of the relational transactions (Fischer et al., 2008).

Relationships between buyers and sellers are among the most commonly investigated types of relationship in expert literature. In recent years, it has been generating considerable interest, especially in relation to rural areas. In this context, the relationship between farmers and buyers is a primary concern for researchers and other professionals in Albania. In literature, there seems to be a consensus on the importance of this relationship, however there are some discordances concerning the factors that may influence it. Influencing factors are numerous, however, what is generating constant debate between the experts is the role of satisfaction, commitment, and trust. They are considered to be integral parts of the relationship quality between farmers and buyers.

In this type of discussion, an important factor that should be taken into consideration is contract farming. Contract farming is widely discussed in literature. There is no exact definition regarding this concept in literature though, but rather different definitions instead, varying from country to country (Will, 2013). In general terms, contract farming refers to a formal process that allows farmers to sell their products based on a previously reached agreement, resulting in higher incomes, productivity, and growth (Bellemare \& Bloem, 2018; Evteeva, Rovný, \& Petril’ák, 2019; Tarí, Pereira-Moliner, Molina-Azorín, \& López-Gamero, 2020). These agreements can be verbal or written. In Albania, written contracts in farming are uncommon because the agricultural market is mainly oriented by spot market transactions completed through verbal agreements (Imami, Zhllima, Viaggi, \& Bokelmann, 2013; Kittova \& Steinhauser, 2018). Agriculture is the main source of Albania's national income and the main sector of employment, being the greatest contributor to GDP, at around 19\% (INSTAT, 2020).

The aim of our work is to broaden the current knowledge regarding farmers' plans for future economic activities as a function of the market information and the farmer-buyer relationships. 


\section{LITERATURE REVIEW}

\subsection{Relationship quality and plans for future activity}

There are numerous factors that affect farmers' plans for future activity. In Albania, majority of farms are limited to 'family management'. In this context, decisions on resources management in the future, are mostly family-oriented. However, along with this factor, there are also other factors that seem to have an impact in farmers' decision-making. Concepts like satisfaction, commitment, and trust are considered as crucial factors when it comes to farmers' plans for future activity. Batt and Wilson (2000) use these concepts in their study to describe the nature of supplier-buyer relationships. In the context of this paper's concern, these factors are shown to be crucial even in farmers' relationship with the buyers of their products. Despite the great interest shown in this topic, in Albania there are only a few researchers, to the best of our knowledge, who have studied this relationship. The question of whether satisfaction, commitment, and trust significantly influences farmers' plans for future activity has been long debated by numerous authors. However, despite the great interest shown on this case, it seems there is yet to be explicit conclusions in the literature regarding this relationship.

Satisfaction is a relatively new concept in the literature and has attracted a lot of interest from the experts of the field. In fact, several authors have attempted to define satisfaction, especially in the economic point of view, but there is yet to be a generally accepted definition. Gruen et al. (2000) use the term 'satisfaction' to refer to the degree to which the business aspect of a relationship delivers fundamental value. On the other hand, satisfaction is sometimes equated with the degree to which each partner involved in the economic relationship is satisfied with the performance of the other. Batt (2004) considers satisfaction to be highly influenced by positive economic rewards. Greater mutual satisfaction in a trading relationship implies more sustainability, continuity, and trust between the trading partners (Fischer \& Reynolds, 2010). What is more, satisfaction is a theoretical concept that is often related to commitment and trust in a relationship with business background. Higher levels of satisfaction are shown to have a positive correlation with trust and commitment, which indeed is considered to be key in maintaining a long-term relationship (Narayandas \& Rangan, 2004).

Satisfaction is a psychological factor that is believed to have a great influence in individuals' decisionmaking. Farmers' plans for future activity do not make an exception from this assumption. In their recent empirical study, Elias et al. (2015) relate satisfaction with farmers' plans for the future, more concretely, with their farm extension intentions. They state that factors like perceived economic return can affect farmers' satisfaction and their plans for future investments. In addition, they relate farmers' plans for future with their age. Authors show that older farmers are less willing to invest in extending their economic activity due to their low risk tolerance. On the other hand, young farmers tend to be more willing to implement innovative technologies on their farm.

In their recent study, Dlamini-Mazibuko et al. (2019) show that in their relationship with the buyer, farmers derive satisfaction mainly from the price offered. On the other hand, they suggest that trust is derived from satisfaction, communication and duration of the relationship, and last but not the least, commitment is derived from trust. The same logic is followed by Parvatiyar and Sheth (2001) who state that high levels of performance satisfaction makes trading partners more motivated to continue the economic relationship.

Another important theoretical factor that is considered to have an impact on farmers' plans for future activity is commitment. A number of authors consider long-term commitment to exist in those trading relationships that are based on satisfaction and trust. Commitment is often referred to as the desire to continue the relationship, along with the willingness to make sacrifices, have confidence and invest on 
it (Kim \& Frazier, 1997). Commitment is often seen as the value of the relationship between the trading partners (Masuku, Kirsten, Van Rooyen, \& Perret, 2003). In their study, Hartmann et al. (2010) state that commitment promotes stability in a trading relationship. They show that committed trading partners have higher chances to continue working with each other. Following this logic, farmers who have higher levels of commitment with their buyers, tend to have greater sustainability and continuity in their relationship. Long term trading relationship, from the financial point of view, means a higher level of income for the farmers. In the same logic line are MacChiavello and Morjaria (2015) who support the idea that sellers, which in this case are farmers, can plan their future production activities better in a situation where buyers show higher levels of commitment to the relationship.

Based on the literature of the field, in the variety of theoretical factors that affect farmers' plans for future activity, besides satisfaction and commitment, this paper has also considered trust. It is widely known as one of the most important factors in a trading relationship. Trust literally shows the degree to which one trading partner views another partner as being honest (Roberts-Lombard, Mpinganjira, \& Svensson, 2017). Among others, trading relationships are always under the pressure of uncertainties. Therefore, trust is seen as an essential factor on reducing the level of these uncertainties (Li \& Nicholls, 2000). This circumstance can be crucial at different stages of consumers' familiarity with firms (Nikodemska-Wołowik et al., 2020), divers levels of supply chain performance (Pakurár et al., 2019). As stated by Masuku et al. (2003), trust is related with contractual commitment between sellers and buyers. The presence of the trust in a trading relationship does not necessarily show that there is no conflict; however, the authors show that it reduces the thread of conflict. In other words, higher levels of trust in a trading relationship imply lower probability that one partner will act opportunistically when he/she has the opportunity to do so. According to Schulze and Spiller (2006), for the creation of the trust in a trading relationship, management actions and the manner of communication are vital. On the other hand, Czernek (2017) supports the idea that trust reduces transaction costs.

As we previously mentioned, there are many papers that aim to address this problem, but it seems there are yet to be explicit conclusions on how satisfaction, trust, and commitment affect farmers' plans for future activity. From the literature review, we can say that higher levels of satisfaction, trust, and commitment show a better relationship quality between farmers and the buyers. The majority of authors are in the same line - satisfaction, trust, and commitment in farmers' relationship with the buyers promotes prolonged trading relationships between them. Indeed, this implies an improved trading relationship for the farmer, stable number of sales, and as a consequence, higher incomes. In theory, higher incomes make the farmers more predisposed to future investments, ceteris paribus, since there are many other significant influencing factors. However, there is still some ambiguity when it comes to a possible direct relationship farmers' plans for future activity with between satisfaction, trust, and commitment.

\subsection{The role of information}

Information is crucial for increasing agricultural production and improving marketing and distribution strategies (Rehman, Muhammad, Ashraf, Ch, \& Ruby, 2013; Ugboma, 2010). Its role cannot be over emphasized in enhancing the agricultural development. The most commonly used sources of information were fellow farmers, printed material, television, and private sector (Rehman et al., 2013). This information flow has helped farmers expand their market choices (Amaya \& Alwang, 2011). These choices can be also expanded in case of appropriate information support from local community stakeholders (Alobaidi \& Kitapci, 2019; Kostiukevych et al., 2020). Farmers with more access to information, what the above statement also indicates, that of including participation in relevant farming 
organisations, usage of cell phone or other internet devices, are more likely to enter into contract farming (Anim, 2011). Studies by Kamara et al. (2006) indicate that farmer organisations, for example, commodity organisations are believed to be centres of information which can be accessed by farmers. Members and individuals can also be motivated by other farmers to join beneficial organisations such as contract farming. Larger social networks imply more representative and trustworthy sources of information, allowing farmers to take better decisions, chose their traders, get access to better contracting, improve their living conditions and earnings and increasing agricultural productivity (Nazari \& Hasbullah, 2008). Information exchange in the other hand is positively influenced by horizontal relationship only in contracted production (Ik \& Azeez, 2020). This supports previous evidence and suggests that in spot markets the interaction of farmers does not enable them to improve information exchange with buyers (Brito et al., 2015). A good explanation may be that the level of information exchange in contracted production is higher than in spot markets (Martins, Trienekens, \& Omta, 2019). However, other researchers claim the opposite, that government extension services advice to the farmer do not appear to have any significant effect on farmers' engagement in contract farming (Xhoxhi, Keco, Skreli, Imami, \& Musabelliu, 2019).

Relationship-specific investments (communication and training) by the buyer motivates both trading partners to maintain the relationship (Batt, 2003; Naidu, 2016; Kelić, Erceg, \& Čandrlić Dankoš, 2020). Such investments offer mutual benefits to trading partners; formal markets may offer inputs and technical support to ensure the product meets the quality and quantity requirements (Boselie, Henson, \& Weatherspoon, 2003). Therefore, the provision of training and communication between the two parties is expected to also improve relationship satisfaction.

Similarly, farmer's commitment in the relationship with its buyer is influenced by the level of information is shared between the trading partners. In cases when the farmers have the chances to get the information to understand the needs of the buyer, receive information about the quality and standard of products and get information on the prices of the products you sell, then their commitment in the relationship can be higher. Nowadays such opportunities become more available due to the extensive use of e-commerce tools, including relatively simple their form of social media communications with buyers (Bilan et al., 2019; Roudposhti et al., 2018).

There has been a growing interest in contract farming among small-scale farmers worldwide as a means to enter the mainstream of the economy (Anim, 2011; Kóródi, \& Dávid, 2019). Recent years have seen considerable interest in the impact of contract farming on farmers in developing countries, motivated out of belief that contract farming spurs transition to modern agriculture (Wang, Wang, \& Delgado, 2014). Studies show that contract farming appears to have been largely successful in improving farmer income and productivity having a significant effect on improving farm efficiency and the efficiency of the supply chain. Because when segmented small operations are pooled together when contracting with a large firm, they can use larger equipment, adopt state-of-the-art technology in production, reduce transaction cost in the supply chain, and make food traceable. This indicates that contract farming can serve as a vehicle to modernize small farm-based agriculture in developing countries. However, the opposite aspects of contract farming, studies have shown that contract farming can pose a risk source in the farm operation thus, leading to potential disadvantages for farmers (Anim, 2011). According to Eaton and Shepherd (2001), most of these negative aspects arise from the relationship between farmers and the agribusiness firms offering the contracts.

Scholars argues that consistency with relationship-specific investments by one partner in a trading increases dependence by the other partner (Çerri, 2012; Dlamini-Mazibuko, Ferrer, \& Ortmann, 2019). In this context, it can be said that shared information improves planning, collaboration, mutual trust and understanding in an exchange (Boselie et al., 2003; Msemwa, Ruoja, \& Kazungu, 2017). Handfield et al. 
(2006) concludes that communication established through ineffective lines have an impact on trust. Trust is stronger in cases when parties believe that both of them are worried about one another's welfare, which could be through clarifying the needs of each partner (Roberts-Lombard et al., 2017). Therefore, a positive relationship between access to information and trust is expected.

In the study conducted by Fritz and Fischer (2007), the estimation results imply that trust levels in a buyer/supplier relationship are positively affected by good communication, which is realized by the frequency of communication and the quality of the information, and a positive past collaboration. However, the existence of personal bonds does not always play a role but seems still to be important when dealing with farmers. According to Yee and Yeung's (2002) exploratory research on trust building in livestock farmers, information is positively related to trust in business behaviour and customer behaviour as well. Increasing the quality of the transmitted information, all other things being equal, trust may immediately be created at a business partner who anticipates from the availability of high quality information on the reliability and trustworthiness of his future business behaviour. In order to gain trust, farmers are to provide trustful information to consumers in order that the latter can calculate or forecast their intentions. In other words, trust will emerge if consumers would be able to predict the farmers' future behaviour with accuracy according to the information provided. Consumer trust is seen to be crucial especially during the period of food safety concerns. Trustful information is the most important factor followed by care, honesty and fairness leading consumers to build trust in farmers. These factors of trust can be developed through social relationships, as they are more of interpersonal factors than individual factors (Yee \& Yeung, 2002).

\section{AIM, METHODOLOGY AND DATA}

The study aim is to investigate the effect of relationship quality on plans for future activity. Special attention is given to the role of information in the market in the above relationships. Hence, it is expected to investigate exists information in the market on relationship quality (satisfaction, commitment, and trust) and plans for future activity.

This research is based in collecting data in the field using a structured questionnaire. Prior to the development of the questionnaire, an in-depth literature review was done with the aim to identify the gaps and construct the variables. Its main modules are: general information for the household, different aspects focused on livelihood, main activity, and trading relationship.

The data collection phase was finished in January 2020, which lasted two months. There were collected 403 valid questionnaires covering different areas where agribusiness is present in Albania. Table 1 informs about the sample profile of the respondents.

The dependent variable in this study is plans for future activity. Plans for future activity is a dummy variable (Yes/No), where respondents were asked to answer to the following question: Is the family interested to increase its agricultural activity?

Relationship quality is represented by three variables, which are: satisfaction, commitment and trust. Satisfaction is measured using a five-point Likert scale, where the options for this question "how satisfied or unhappy are you with each of the elements below regarding trade relations with your buyer" are: Level of information exchange, Offered price, and Fairness of earnings distribution (between you and the buyer). Commitment and trust were measured with different sets of statements (see Table 2) answering to the main question "please indicate how much you agree or disagree with each of the below sentences" with a five-point Likert scale: 1 = I do not agree at all, $2=\mathrm{I}$ don't agree, $3=$ Somewhat agree, $4=\mathrm{I}$ agree, $5=\mathrm{I}$ agree very much. 
Sample profile

\begin{tabular}{|c|l|c|c|c|}
\hline & \multicolumn{1}{|c|}{ Category } & \multicolumn{2}{c|}{ Interested to increase farm's activity } & Total \\
\hline \multicolumn{1}{|c|}{ Variable } & No $(n=300)$ & Yes $(n=103)$ & $(n=403)$ \\
\hline Municipality & Has & $9.67 \%$ & $9.71 \%$ & $9.68 \%$ \\
\hline & Ura Vajgurore & $12.33 \%$ & $21.36 \%$ & $14.64 \%$ \\
\hline & Maliq & $16.33 \%$ & $3.88 \%$ & $13.15 \%$ \\
\hline & Lushnje & $48.67 \%$ & $42.72 \%$ & $47.15 \%$ \\
\hline & Konispol & $13.00 \%$ & $22.33 \%$ & $15.38 \%$ \\
\hline \multirow{2}{*}{$\begin{array}{c}\text { Education of } \\
\text { the respondent }\end{array}$} & Elementary-up to 4 years & $8.67 \%$ & $4.85 \%$ & $7.69 \%$ \\
\cline { 2 - 5 } & Secondary-8/9 years & $55.67 \%$ & $57.28 \%$ & $56.08 \%$ \\
\hline & High School & $24.67 \%$ & $26.21 \%$ & $25.06 \%$ \\
\hline \multirow{2}{*}{$\begin{array}{c}\text { Age of } \\
\text { respondent }\end{array}$} & Professional High School & $8.33 \%$ & $5.83 \%$ & $7.69 \%$ \\
\hline & University & $2.67 \%$ & $5.83 \%$ & $3.47 \%$ \\
\cline { 2 - 4 } & $25-34$ years old & $5.00 \%$ & $6.80 \%$ & $5.46 \%$ \\
\hline & $45-54$ years old & $6.67 \%$ & $9.71 \%$ & $7.44 \%$ \\
\hline & $55-64$ years old & $19.33 \%$ & $21.36 \%$ & $19.85 \%$ \\
\hline & $65+$ years old & $29.67 \%$ & $41.75 \%$ & $32.75 \%$ \\
\hline
\end{tabular}

Source: own compilation.

Information was measured as a composite variable of three statements answering to the question "What is your chance to....?" which are: get the information to understand the needs of the buyer, receive information about the quality and standard of products, and get information on the prices of the products you sell. The possible answer to each of this statements were: $1=$ Very low, $2=$ Low, $3=$ Medium, 4=High, $5=$ Very high.

In addition to the above variables, age, education and income from agricultural activities are included in the analysis as control variables with the aim to avoid any potential causal effect on plans for future activity in the farm.

To test the proposed relationships, partial least squares method of structural equation modelling (PLS-SEM) was used (Hair, Hult, Ringle, \& Sarstedt, 2017). It was used this type of method because this kind of research requires latent variables to continue the analysis (Hair, Risher, Sarstedt, \& Ringle, 2019). Reflective indicators were all the constructs. The analysis of PLS-SEM was performed in SmartPLS 3.0 (Ringle, Wende, \& Becker, 2015). As it is required, a bootstrap procedure with 5000 iterations of resampling was followed to assess the standardized paths between the measured constructs (Hair et al., 2017).

\section{RESULTS}

Prior of testing the formulated relationships, a preliminary check of the assumptions was done. Attention was given to the assumptions of the PLS-SEM method such as loadings, collinearity, scale reliability, and discriminant validity among the measured constructs. The lowest loading was 0.834 , which is above the threshold of 0.70 (see Table 2). All the variance inflation factor (VIF) values were reported to be lower than 3, meaning the absence of multicollinearity in the research. In Table 2 are also displayed the 
results of the reliability analysis for the constructs of the present study. The results of the analysis indicates that the four composed variables have good scale reliability since the Cronbach's alpha and composite reliability values are above 0.80 .

Table 2

Loadings of the items and reliability analysis

\begin{tabular}{|l|c|}
\hline \multicolumn{1}{|c|}{ Items } & Loading \\
\hline Commitment (Cronbach's Alpha $=0.869$, Composite Reliability = 0.920) & 0.892 \\
\hline I would like to strengthen the business relationship with the main buyer in the future & 0.900 \\
\hline I believe that in the long term the relationship with the principal purchaser will be profitable & 0.879 \\
\hline I would find it easy to replace the business relationship with the main buyer & 0.935 \\
\hline Information (Cronbach's Alpha =0.928, Composite Reliability =0.954) & 0.942 \\
\hline get the information to understand the needs of the buyer & 0.928 \\
\hline receive information about the quality and standard of products & 0.895 \\
\hline get information on the prices of the products you sell & 0.847 \\
\hline Satisfaction (Cronbach's Alpha $=0.843$, Composite Reliability $=0.906)$ & 0.876 \\
\hline Level of information exchange & \\
\hline Offered price & 0.903 \\
\hline Fairness of earnings distribution (between you and the buyer) & 0.854 \\
\hline Trust (Cronbach's Alpha = 0.882, Composite Reliability =0.919) & 0.834 \\
\hline I trust the information the buyer gives me (e.g. market prices) & 0.845 \\
\hline Generally, my primary buyer does not take actions that could harm my business & \\
\hline I trust my buyer & \\
\hline The promises made by my buyer are reliable & \\
\hline
\end{tabular}

Note: COM, Commitment; INFO, Information; SAT, Satisfaction; TR, Trust.

Source: own calculation.

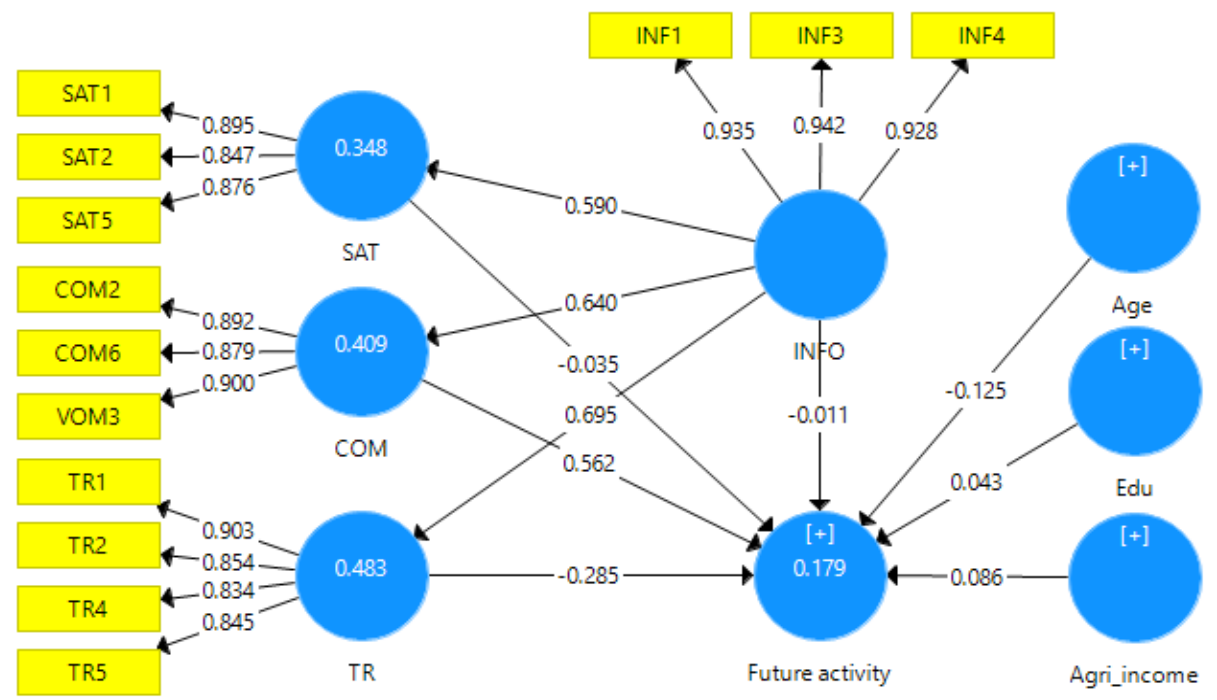

Figure 1. Model measurement

Note: COM, Commitment; INFO, Information; SAT, Satisfaction; TR, Trust. Source: own compilation. 
Figure 1 shows the results of the model measurement in a schematic way. It was found that information explains $34.8 \%$ of the variation of satisfaction, $40.9 \%$ of the variation of commitment, and $48.3 \%$ of the variation of trust. The model explains $17.9 \%$ of the variation of plans for future activities. As it can be seen in the figure, age and highest education level completed of the respondent, and income of the households from the agricultural activity are used in this research as control variables.

In addition to the above analysis, discriminant analysis was done, which represent an assumption of the model. Analysis demonstrated that the construct variables were distinct from one another since all the Heterotrait-Monotrait coefficients were smaller than 0.85 (Henseler, Ringle, \& Sarstedt, 2015) (see Table 3). Based on the above results, according to Hair et al.'s (2019) principles in using such models in SmartPLS, the PLS-SEM assumptions were satisfied. This information means that the processed analysis and results by the PLS-SEM method can be interpreted and discussed.

Table 3

Discriminant analysis and correlation coefficients

\begin{tabular}{|l|c|c|c|c|}
\hline & COM & INFO & SAT & TR \\
\hline COM & & 0.640 & 0.529 & 0.727 \\
\hline INFO & 0.712 & & 0.590 & 0.695 \\
\hline SAT & 0.618 & 0.665 & & 0.697 \\
\hline TR & 0.824 & 0.765 & 0.805 & \\
\hline
\end{tabular}

Note: COM, Commitment; INFO, Information; SAT, Satisfaction; TR, Trust. Correlation above, HTMT below the diagonal.

Source: own calculation.

The results of the structural model are summarized in Table 4 and displayed in Figure 2.

Table 4

Hypotheses testing

\begin{tabular}{|l|l|c|c|c|}
\hline \multicolumn{1}{|c|}{ Source of the effect } & \multicolumn{1}{|c|}{ Path } & Coefficient & $t$ & $p$ \\
\hline Relationship quality & SAT $\rightarrow$ Future activity & -0.035 & 0.522 & 0.602 \\
\hline & COM $\rightarrow$ Future activity & 0.562 & 7.802 & 0.000 \\
\hline & TR $\rightarrow$ Future activity & -0.285 & 3.372 & 0.001 \\
\hline Information & INFO $\rightarrow$ Future activity & -0.011 & 0.160 & 0.873 \\
\hline & INFO $\rightarrow$ COM & 0.640 & 16.260 & 0.000 \\
\hline & INFO $\rightarrow$ SAT & 0.590 & 12.889 & 0.000 \\
\hline & INFO $\rightarrow$ TR & 0.695 & 18.349 & 0.000 \\
\hline Control variables & Age $\rightarrow$ Future activity & -0.125 & 2.600 & 0.009 \\
\hline & Edu $\rightarrow$ Future activity & 0.043 & 0.915 & 0.360 \\
\hline & Agri_income $\rightarrow$ Future activity & 0.086 & 1.674 & 0.094 \\
\hline
\end{tabular}

Note: COM, Commitment; INFO, Information; SAT, Satisfaction; TR, Trust.

Source: own calculation.

The tested paths are grouped into three main categories. The first group of tested linkages are those between relationship quality (satisfaction, commitment, and trust) and future activity. It was found that future activity is not influenced by satisfaction of the relationship $(\beta=-0.035, p>0.10)$, meaning that farmer's satisfaction in the relationship with the main buyer does not matter for future activity in the farm. On the other hand, it was found evidence in support of the relationship between future activity and 
commitment $(\beta=0.562, p<0.001)$ and trust $(\beta=-0.285, p<0.001)$. As the results indicate, commitment positively affect plans for future activities in the farm, meaning that the higher the farmer's commitment in the relationship with the main buyer, the higher are the chances to plan for future activities in the farm. On contrary, trust negatively influences plans for future activity, indicating that chances to plan for future activity in the farm reduce as farmer's trust in the relationship with the buyer increases.

The second group of tested paths are those who originate from information and points to either future activity or relationship quality (satisfaction, commitment, and trust). Evidence shows that information positively influences relationship quality. Hence, information positively and significantly influences farmer's satisfaction $(\beta=0.640, p<0.001)$, commitment $(\beta=0.590, p<0.001)$, and trust $(\beta=$ $0.695, p<0.001)$ in the relationship with its main buyer. The analysis showed that future activity is not influenced by information $(\beta=-0.011, p>0.10)$.

The third group of tested paths includes the effects of control variables on future activity. The analysed data demonstrates that age significantly affects farm's future activity $(\beta=-0.125, p<0.01)$, meaning that the age of the farmer is an important factor in deciding to go further with plans for future activities. The negative relationship between age and future activity indicates that younger farmers have higher chances to increase the agricultural activity. It is interesting that education was found to be an insignificant factor for future activity in the farm $(\beta=0.043, p>0.10)$. Family income from agricultural activity is found to be a positive influencer for plans in future activity $(\beta=0.086, p<0.10)$. This result shows that as the family income from agricultural activity increases, the chance to plan future activity increases. Education was not a significant factor for plans for future activities in the farm $(\beta=0.043, p>$ $0.10)$.

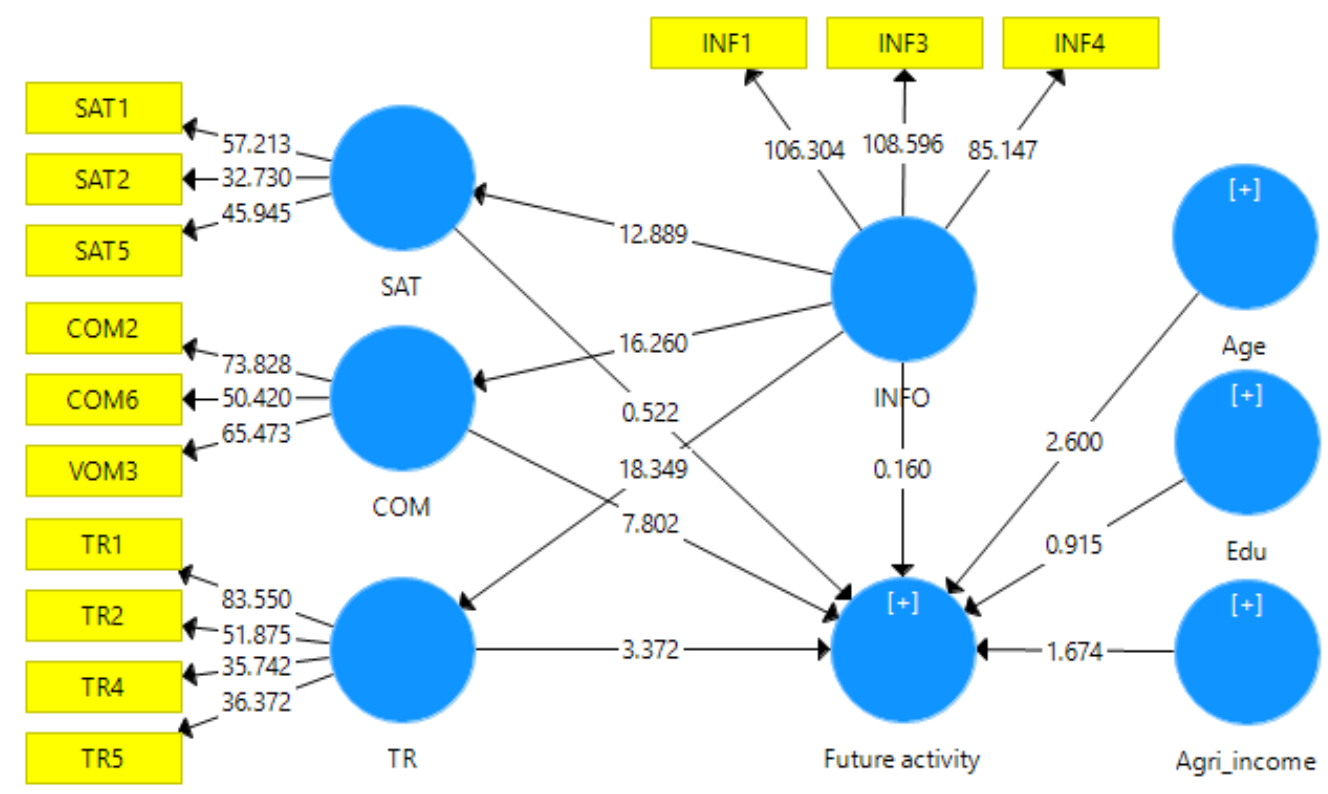

Figure 2. Hypotheses testing

Note: COM, Commitment; INFO, Information; SAT, Satisfaction; TR, Trust.

Source: own compilation. 


\section{DISCUSSION}

The current research's findings shed lights on the role of information on market in relationship quality between trading partners and plans for future activities. The literature in the field of this study has shown that communication, in general, and information on different aspects of the market, in particular, influence different aspects of trading relationship including relationship quality and participation in horizontal arrangements (Brito et al., 2015; Nazari \& Hasbullah, 2008; Schulze, Wocken, \& Spiller, 2006). In this line, to capture the whole nature of information needed for the buyer-supplier relationship, Msemwa et al. (2017) propose five aspects of information, which are: reliability of information, willingness to disseminate meaningful information, timeline of information, credibility of information, responsiveness to share information. Hence, information on market is not a factror that can be composed by only one variable, but as it includes different asspects of the trading relationship between partners. Following this logic, in this paper, information on market is measured as a composite variable of a set of statements, as listed in the prior sections of the paper.

This paper identifies that relationship quality between parties is influenced by information on market. The findings of this study show that farmer's satisfaction, commitment and trust in the trading relationship with the main buyer are significantly affected by information on market. As a result, information shared between the trading partners can improve the level of farmer's satisfaction, commitment and trust in the relationship. Thus, the higher the shared information on market between trading partners, the higher the level of satisfaction, commitment and trust in the relationship with the buyer.

There are scholars such as Ratinger and Bošková (2013) and Fernandez-Stark et al. (2012), who states that managerial decisions taken by farmers are affected by information regarding the market. In this line, Brito et al. (2015) concluded that dairy farmers who participate in horizontal arrangements have greater access to general information related to dairy activity, compared to those who do not participate in horizontal arrangements. Contrary to the above authors, this study failed to demonstrate any direct significant linkage between information about the market and farmer's plans for future activity. Therefore, the evidence of this research shows that the effect of information on market do not matter on plans for future activities in the farm.

On the other hand, this research informs that farmer's plans for future actively is determined partly by relationship quality, since the results show that commitment and trust significantly influence on the interest to increase the agricultural activity, whereas satisfaction was found to have insignificant effect on such interest. In addition to these factors, farmer's age and income from agricultural activity affect plans for future activity. However, it is interesting to mention that as younger the farmer, the higher chances to have interest in increasing the agricultural activity in the future. As expected, income from agricultural activity and plans for future activity are positively related, meaning that the higher the income from agricultural activity, the higher are chances to plan future activities in the farm.

\section{CONCLUSION}

This study sought to shed light over the role of information on market in relationship quality between farmer and buyer and plans for future activities in the farm. Communication and shared information between the trading partners is a current topic in particular for an agribusiness context. The role of information on relationship quality is investigated in a developing country like Albania, where institutions are weak and the competitions principles from advance economies are not corrected adopted (Çera, Breckova, Çera, \& Rozsa, 2019). Even though there are some studies which informs on the above 
issues, yet there is a need to better understand the whole picture when it comes to the trading relationship. This study aims to contribute to fill in such gap in the literature.

To the best of the authors' knowledge, the linkages between information on market and plans for future activities has not received much attention by scholars. Besides, it can be stated that this research is among the first attempts which fills such gap in the literature, since we have failed to find any other study pointing to such issue. In addition, the originality of this work lies in the fact that the effects of information on market on both relationship quality and plans for future activities in the farm.

This paper shows that information on market improves the overall relationship quality between farmer and its main buyer. On the other hand, such information does not matter for the plans for future activities.

The study is not free of its limitations. First, the data covers only one country. It could be better to include in the analysis other countries in order to investigate the role of culture in such relationships. Second, the results of PLS-SEM method can be compared with the results of a logistic regression. The use of two methods is expected to bring more sound results.

As future research can be consider a more in-depth analysis of the linkages between information on market with different aspects of trading relationship. One issue is to investigate the indirect effect of information on market on plans for future activities. Researchers are suggested to pay attention to the above linkages. It is expected that relationship quality mediates the effect of shared information on market between trading partners on plans for future activities in the farm.

\section{REFERENCES}

Alobaidi, M., \& Kitapci, O. (2019). Strategic Orientation, Market Orientation and Business Performance: in Searching for Integration, Evidence from Turkey. Montenegrin Journal of Economics, 15(3), 53-70.

Amaya, N., \& Alwang, J. (2011). Access to Information and Farmer's Market Choice: The Case of Potato in Highland Bolivia. Journal of Agriculture, Food Systems, and Community Development, 1(4), 35-53. https://doi.org/10.5304/jafscd.2011.014.003

Anim, F. D. K. (2011). Small-scale maize farmers' decision to participate in contract farming: Implications for integration into the marketing chain. African Journal of Business Management, 5(13), 5065-5069. https://doi.org/10.5897/AJBM10.249

Batt, P. J. (2003). Examining the performance of the supply chain for potatoes in the Red River Delta using a pluralistic approach. Supply Chain Management. https://doi.org/10.1108/13598540310500277

Batt, P. J. (2004). Incorporating Measures of Satisfaction, Trust and Power-dependence into an Analysis of Agribusiness Supply Chains. In G. I. Johnson \& P. J. Hofman (Eds.), Agriproduct Supply-Chain Management in Developing Countries (pp. 27-43). Bali. Retrieved from https://www.researchgate.net/publication/52004875

Batt, P. J., \& Wilson, H. (2000). Exploring The Nature Of Buyer-Seller Relationships In The Western Australian Wine Industry. In A. O’Cass (Ed.), ANZMAC 2000. Visionary Marketing for the 21st Century: Facing the Challenge (pp. 61-66). Retrieved from https://espace.curtin.edu.au/handle/20.500.11937/32006

Bellemare, M. F., \& Bloem, J. R. (2018). Does contract farming improve welfare? A review. World Development, 112, 259-271. https://doi.org/10.1016/j.worlddev.2018.08.018

Bilan, Y., Mishchuk, H., Samoliuk, N., \& Grishnova, O. (2019). ICT and Economic Growth: Links and Possibilities of Engaging. Intellectual Economics, 13(1). DOI: https://doi.org/10.13165/IE-19-13-1-07

Boselie, D., Henson, S., \& Weatherspoon, D. (2003). Supermarket Procurement Practices in Developing Countries: Redefining the Roles of the Public and Private Sectors. American Journal of Agricultural Economics, 85(5), 11551161. https://doi.org/10.1111/j.0092-5853.2003.00522.x

Brito, M. M. de, Bánkuti, F. I., Bánkuti, S. M. S., Ferreira, M. C. M., Damasceno, J. C., Santos, G. T. dos, \& Zambom, M. A. (2015). Horizontal arrangements: strategy for reducing the asymmetry information for dairy farmers in Paraná, Brazil. Ciência Rural, 45(11), 2069-2075. https://doi.org/10.1590/0103-8478cr20141724 
Çera, G., Breckova, P., Çera, E., \& Rozsa, Z. (2019). The Effect of Business Enabling Policies, Tax Treatment, Corruption and Political Connections on Business Climate. Acta Polytechnica Hungarica, 16(4), $113-132$. https://doi.org/10.12700/APH.16.4.2019.4.6

Çerri, S. (2012). Exploring factor affecting trust and relationship quality in a supply chain context. Journal of Business Studies Quarterly, 4(1), 74-90.

Czernek, K., Czakon, W., \& Marszałek, P. (2017). Trust and formal contracts: complements or substitutes? A study of tourism collaboration in Poland. Journal of Destination Marketing and Management, 6(4), 318-326. https://doi.org/10.1016/j.jdmm.2017.07.001

Dlamini-Mazibuko, B. P., Ferrer, S., \& Ortmann, G. (2019). Examining the farmer-buyer relationships in vegetable marketing channels in Eswatini. Agrekon, 58(3), 369-386. https://doi.org/10.1080/03031853.2019.1596824

Eaton, C., \& Shepherd, A. (2001). Contract Farming: Partnerships for Growth - Agricutura Services Buletin.

Elias, A., Nohmi, M., Yasunobu, K., \& Ishida, A. (2015). Farmers' Satisfaction with Agricultural Extension Service and Its Influencing Factors: A Case Study in North West Ethiopia. Journal of Agricultural Science and Technology (Vol. 18). Retrieved from https://jast.modares.ac.ir/browse.php?a_code=A-23-10004982\&slc_lang=en\&sid=23

Evteeva, T., Rovný, P., \& Petril'ák, M. (2019). Farm as a form of small agricultural business in Russia: advantages and disadvantages. International Journal of Entrepreneurial Knowledge, 7(2), 53-62. https://doi.org/10.37335/ijek.v7i2.93

Fernandez-Stark, K., Bamber, P., \& Gereffi, G. (2012). Inclusion of Small-and Medium-Sized Producers in HighValue Agro-Food Value Chains. Citeseer. Retrieved from www.cggc.duke.edu.

Fischer, C., Hartmann, M., Reynolds, N., Leat, P., Revoredo-Giha, C., Henchion, M., \& Gracia, A. (2008). Agri-food chain relationships in Europe - empirical evidence and implications for sector competitiveness. In 12th Congress of the European Association of Agricultural Economists (pp. 1-12). Ghent. Retrieved from https://ageconsearch.umn.edu/record/44265/

Fischer, C., \& Reynolds, N. (2010). Collaborative Advantage, Relational Risks and Sustainable Relationships: a Literature Review and Definition. In C. Fischer \& M. Hartmann (Eds.), Agri-food Chain Relationships (pp. 7587). Retrieved from https://www.researchgate.net/publication/268292038

Fritz, M., \& Fischer, C. (2007). The role of trust in European food chains: Theory and empirical findings. International Food and Agribusiness Management Review, 10(2), 141-161. https://doi.org/10.22004/ag.econ.8185

Gruen, T. W., Summers, J. O., \& Acito, F. (2000). Relationship marketing activities, commitment, and membership behaviors in professional associations. Journal of Marketing, 64(3), 34-49. https://doi.org/10.1509/jmkg.64.3.34.18030

Hair, J. F., Hult, G. T. M., Ringle, C. M., \& Sarstedt, M. (2017). A Primer on Partial Least Squares Structural Equation Modeling (2nd ed.). Los Angelos: Sage.

Hair, J. F., Risher, J. J., Sarstedt, M., \& Ringle, C. M. (2019). When to use and how to report the results of PLS-SEM. European Business Review, 31(1), 2-24. https://doi.org/10.1108/EBR-11-2018-0203

Handfield, R., Krause, D. R., \& Scannell, T. V. (2006). Avoid the pitfalls in supplier development. In E. Rhodes, J. Warren, \& R. Carter (Eds.), Supply Chains and Total Product Systems: A Reader (pp. 158-176). Oxford. Retrieved from https://books.google.al/books?hl=en\&lr=\&id=j3g4uUrVKIQC\&oi=fnd\&pg=PA158\&dq= Avoid+the+pitfalls+in+supplier+development.\&ots=Dja3EagAxF\&sig=khgGjjuko5ItkvxGxtCM3fetoaI\&r edir_esc $=\mathrm{y} \# \mathrm{v}=$ onepage $\& \mathrm{q}=$ Avoid the pitfalls in supplier development.\&f $=$ false

Hartmann, M., Frohberg, K., \& Fischer, C. (2010). Building sustainable relationships in agri-food chains: Challenges from farm to retail. In Agri-food Chain Relationships (pp. 25-44). CABI Publishing. https://doi.org/10.1079/9781845936426.0025

Henseler, J., Ringle, C. M., \& Sarstedt, M. (2015). A new criterion for assessing discriminant validity in variancebased structural equation modeling. Journal of the Academy of Marketing Science, 43(1), 115-135. https://doi.org/10.1007/s11747-014-0403-8

Ik, M. \& Azeez, A. A. (2020). Organisational green behavioural change: The role of Change Management. International Journal of Entrepreneurial Knowledge, 8(1), 34-48. https://doi.org/10.37335/ijek.v8i2.98 
Imami, D., Zhllima, E., Viaggi, D., \& Bokelmann, W. (2013). Between weak markets and weak regulations: Determinants of contracting in orchard farming in Albania. Journal on Chain and Network Science, 13(1), 37-46. https://doi.org/10.3920/JCNS2013.x225

INSTAT. (2020). Gross Domestic Product. https://doi.org/10.1787/g2d71aef-en

Kamara, A., Kureh, I., Menkir, A., Kartung, P., Tarfa, B., \& Amaza, P. (2006). Participatory onfarm evaluation of the performance of droughttolerant maize varieties in the Guinea Savannas of Nigeria. International Journal of Food, Agriculture and Environment, 4, 192-196.

Kim, K., \& Frazier, G. L. (1997). Measurement of distributor commitment in industrial channels of distribution. Journal of Business Research, 40(2), 139-154. Retrieved from https://www.sciencedirect.com/science/article/pii/S0148296396002846

Kittova, Z., \& Steinhauser, D. (2018). The International Economic Position of Western Balkan Countries in Light of their European Integration Ambitions. Journal of Competitiveness, 10(3), 51-68. https://doi.org/10.7441/joc.2018.03.04

Kelić, I., Erceg, A. \& Čandrlić Dankoš, I. (2020). Increasing tourism competitiveness: Connecting Blue and Green Croatia. Journal of Tourism and Services, 20(11), 132-149. doi: https://doi.org/10.29036/jots.v11i20.138

Kostiukevych, R., Mishchuk, H., Zhidebekkyzy, A., Nakonieczny, J., \& Akimov, O. (2020). The impact of European integration processes on the investment potential and institutional maturity of rural communities. Economics and Sociology, 13(3), 46-63. doi:10.14254/2071-789X.2020/13-3/3

Kóródi, M., Dávid, L.D. (2019). The Uniqueness Of The Hungarian Rural Tourism Supply. Journal of Tourism and Services, 10(19): 24-39. https://doi.org/10.29036/jots.v10i19.93

Li, F., \& Nicholls, J. A. F. (2000). Transactional or Relationship Marketing: Detenninants of Strategic Choices. Journal of Marketing Management, 16(5), 449-464. https://doi.org/10.1362/026725700785046001

Macchiavello, R., \& Morjaria, A. (2015). The Value of Relationships: Evidence from a Supply Shock to Kenyan Rose Exports. American Economic Review, 105(9), 2911-2945. https://doi.org/10.1257/aer.20120141

Martins, F. M., Trienekens, J., \& Omta, O. (2019). Implications of horizontal and vertical relationships on farmers performance in the Brazilian pork industry. Livestock Science, 228(August), 161-169. https://doi.org/10.1016/j.livsci.2019.08.013

Masuku, M. B., Kirsten, J. F., Van Rooyen, C. J., \& Perret, S. (2003). Contractual relationships between smallholder sugarcane growers and millers in the sugar industry supply chain in Swaziland. Agrekon, 42(3), 183-199. https://doi.org/10.1080/03031853.2003.9523619

Msemwa, L. S., Ruoja, C., \& Kazungu, I. (2017). Influence of communication in buyer-supplier relationship and the perfomance of maize markets in Hai Diatrict Tanzania. International Journal of Economics, Business and Management Research, 1(02), 89-108. Retrieved from www.ijebmr.com

Muo, I., Azeez, A.. (2019). Green Entrepreneurship: Literature Review and Agenda for Future Research. International Journal of Entrepreneurial Knowledge, 7(2), 17-29. https://doi.org/10.37335/ijek.v7i2.90

Naidu, S. (2016). Building and Managing Long-term Buyer-Seller Relationships in Contract Farming. In International Food and Agribusiness Management Association's (IFAMA) 26th Annual World Forum and Symposium (pp. 25-36). Aarhus: IFAMA.

Narayandas, D., \& Rangan, V. K. (2004). Building and sustaining buyer-seller relationships in mature industrial markets. Journal of Marketing, 68(3), 63-77. https://doi.org/10.1509/jmkg.68.3.63.34772

Nazari, M., \& Hasbullah, A. (2008). Farmers' Approach and Access to Information and Communication Technology in the Efficient use of modern irrigation methods. European Journal of Scientific Research, 21(1), 37-44.

Nikodemska-Wołowik, A., Bednarz, J., Wach, D., Little, J., \& Kubik, M. (2020). Building aware and unaware consumers' trust towards family business: Evidence from Poland. Entrepreneurial Business and Economics Review, 8(3), 135-154. https://doi.org/10.15678/EBER.2020.080308

Pakurár, M., Benedek, S. A., Popp, J., Magda, R., \& Oláh, J. (2019). Trust or doubt: Accuracy of determining factors for supply chain performance. Polish Journal of Management Studies, 19(1), 283-297.

Parvatiyar, A., \& Sheth, J. N. (2001). Customer Relationship Management: Emerging Practice, Process, and Discipline. Journal of Economic and Social Research, 3(2), 1-34. Retrieved from https:/ / citeseerx.ist.psu.edu/viewdoc/download?doi=10.1.1.113.2212\&rep=rep1\&type=pdf 
Ratinger, T., \& Bošková, I. (2013). Strategies and effects of milk producers' organisations in the Czech Republic. Agricultural Economics, 59(3), 113-124. Retrieved from https://www.agriculturejournals.cz/publicFiles/

66_2012-AGRICECON.pdf

Rehman, F., Muhammad, S., Ashraf, I., Ch, K. M., \& Ruby, T. (2013). Effect of farmers' socioeconomic characteristics on access to agricultural information: empirical evidence from Pakistan. Young, 35(52), $21-67$.

Ringle, C. M., Wende, S., \& Becker, J.-M. (2015). SmartPLS. Boenningstedt: SmartPLS GmbH. Retrieved from http://www.smartpls.com

Roberts-Lombard, M., Mpinganjira, M., \& Svensson, G. (2017). Antecedents and outcomes of satisfaction in buyersupplier relationships in South Africa: A replication study. South African Journal of Economic and Management Sciences, 20(1), 1-14. https://doi.org/10.4102/sajems.v20i1.1497

Roudposhti, V.M., Nilashi, M., Mardani, A., Streimikiene, D., Samad, S., \& Ibrahim, O. (2018). A new model for customer purchase intention in ecommerce recommendation agents. Journal of International Studies, 11(4), $237-$ 253. doi:10.14254/2071-8330.2018/11-4/17

Schulze, B., \& Spiller, A. (2006). Determinants of Trust between Buyers and Suppliers in Agribusiness: Empirical Evidence from the German Pork Sector appears on all such copies. Determinants of Trust between Buyers and Suppliers in Agribusiness: Empirical Evidence from the German Pork Sector (No. 737-2016-50901). Retrieved from https://ageconsearch.umn.edu/record/7719/

Schulze, B., Wocken, C., \& Spiller, A. (2006). Relationship quality in agri-food chains: Supplier management in the German pork and dairy sector. Journal on Chain and Network Science, 6(1), 55-68. https://doi.org/10.3920/JCNS2006.x065

Tarí, J. J., Pereira-Moliner, J., Molina-Azorín, J. F., \& López-Gamero, M. D. (2020). A Taxonomy of Quality Standard Adoption: Its Relationship with Quality Management and Performance in Tourism Organizations In Spain. Journal of Tourism and Services, 11(21), 22-37. https://doi.org/10.29036/jots.v11i21.151

Ugboma, M. U. (2010). Access to agricultural information by fish farmers in Niger Delta Region of Nigeria. Library Philosophy and Practice, 2010(9), 1-7.

Wang, H. H., Wang, Y., \& Delgado, M. S. (2014). The transition to modern agriculture: Contract farming in developing economies. American Journal of Agricultural Economics, 96(5), 1257-1271. https://doi.org/10.1093/ajae/aau036

Will, M. (2013). Contract Farming Handbook: A Practical Guide for Linking Small-scale Producers and Buyers Through Business Model Innovation.

Xhoxhi, O., Keco, R., Skreli, E., Imami, D., \& Musabelliu, B. (2019). The role of intermediaries' power on contracting decision between farmers and intermediaries. New Medit, 18(3), 3-15. https://doi.org/10.30682/nm1903a

Yee, W. M. s., \& Yeung, R. M. w. (2002). Trust building in livestock farmers: an exploratory study. Nutrition \& Food Science, 32(4), 137-144. https://doi.org/10.1108/00346650210436244 